\title{
The Difference Between EFL Students' Preferred Learning Styles and EFL Teachers' Preferred Teaching Styles in Saudi Arabia
}

\author{
Sulaiman Alnujaidi ${ }^{1}$ \\ ${ }^{1}$ College of Languages and Translation, Al-Imam Muhammad Ibn Saud University, Riyadh, Saudi Arabia \\ Correspondence: Sulaiman Alnujaidi, English Department, College of Languages and Translation, Al-Imam \\ Muhammad Ibn Saud University, P.O. Box 5701, Riyadh, 11432, Saudi Arabia.
}

Received: November 10, 2018

doi: $10.5539 /$ elt.v12n1p90
Accepted: December 10, 2018 Online Published: December 13, 2018

URL: https://doi.org/10.5539/elt.v12n1p90

\begin{abstract}
This study investigated the difference between EFL students' preferred learning styles (PLS) and EFL teachers' preferred teaching styles (PTS) in Saudi Arabia. The participants in this study were 130 EFL students and 102 EFL teachers. Felder and Silverman's learning/teaching style model was employed to identify students' learning styles as well as teachers' teaching styles. The study's results revealed that EFL students preferred the sensing, visual, active, and sequential learning styles. It was also found that EFL teachers preferred the abstract, verbal, passive, and global teaching styles. The study revealed a statistically significant difference between students' learning styles and teachers' teaching styles. These results showed that there was a mismatch between students' PLS and teachers' PTS and recommendations were proposed to bridge this gap.
\end{abstract}

Keywords: English as a Foreign Language (EFL), Preferred Learning Styles (PLS), Preferred Teaching Styles (PTS), Index of Learning Style (ILS), Index of Teaching Style (ITS)

\section{Introduction}

One of the variables that influence successful EFL learning is the match between learning and teaching styles. Matching learning styles to teaching styles can optimize students' potentials and maximize their learning success. Teachers should identify and match their own teaching styles to their students' learning styles which, in turn, allows teachers to implement more effective instructional methods and tailor more suitable materials and activities that match their students' learning needs.

\subsection{Statement of the Problem}

Some teaching styles can only address the needs of a few students. A student who favors an active learning style, for example, would prefer a teacher who adopts role-playing and group work; whereas a teacher who uses only texts and handouts would prevent a student, who favors visual perception (charts, pictures, and films), from learning effectively. Matching teaching styles to learning styles requires identifying them, minimizing the difference between them, and adopting a variety of teaching styles that accommodate different learning styles. Saudi EFL classrooms need to be closely investigated in order to bridge the mismatch gap between learning and teaching styles. The current study was designed to shed some light on this issue.

\subsection{Purpose of the Study}

This study aimed to answer the following research questions:

1) What are the most preferred learning styles among EFL students?

2) What are the most preferred teaching styles among EFL teachers?

3) Is there a statistically significant difference between students' preferred learning styles and teachers' preferred teaching styles?

\subsection{Significance of the Study}

This study might provide an insight into the importance of matching teaching styles to learning styles in the EFL classroom settings. The results of this study could help EFL teachers identify their own teaching styles as well as their students' learning styles, and match their teaching styles to their students' learning styles through adopting a balanced teaching style that meets their students' learning needs. 


\section{Literature Review}

\subsection{Models of Learning and Teaching Styles}

According to Reid (1995), learning styles are "internally based characteristics, often not perceived or consciously used by learners, for the intake and comprehension of new information" (p. ix). Felder and Henriques (1995) defined learning styles as "ways in which an individual characteristically acquires, retains, and retrieves information" (p. 21). Similarly, Grasha (1996) described learning styles as "personal characteristics that can influence learners' ability to acquire information, interact with others, and participate in activities." (p. 41). Oxford (2001) pointed out that learning styles are general approaches that students prefer to use when they learn a subject, acquire a language, or deal with a problem. Learning styles can be adapted because they are habitual rather than biological attributes; and therefore, students can maximize their potential for learning when they develop an understanding of their own learning styles (Reid, 1995).

To identify learning styles, several models have been proposed by some researchers. One of the well-known learning style models is the Felder-Silverman model, which "classified students according to where they fit on a number of scales pertaining to the ways they receive and process information." (Felder \& Silverman, 1988, p. 674). According to this model, a student's learning style is defined by the answers to four questions: (1) what type of information does the student preferentially perceive: sensory (sights, sounds, physical sensations) or intuitive (memories, thoughts, insights); (2) what type of sensory information is most effectively perceived: visual (pictures, diagrams, flow charts, demonstration) or verbal (written and spoken explanations); (3) how does the student prefer to process information: actively (through engagement in physical activity or discussion) or reflectively (through introspection); and (4) how does the student characteristically progress toward understanding: sequentially in a logical progression of incremental steps) or globally in large jumps (Felder \& Silverman, 1988).

As a result, four dimensions were proposed as corresponding learning styles: (1) Perception (sensing/intuitive) which focuses on how information is perceived. Sensing students favor concrete information, prefer facts and repetition, like solving problems, and tend to be practical; whereas intuitive students favor abstract information, prefer theories and interpretations, like discovering relationships, and tend to be conceptual.; (2) Input (visual/verbal) which focuses on how information is presented. Visual students favor pictures, diagrams, flow charts, and experiments and like information to be shown rather than told; whereas verbal students prefer written and spoken explanations, and like information to be told rather than shown; (3) Processing (active/reflective) which focuses on how information is processed. Active students like to try things out and prefer learning in groups; whereas reflective students like to think things through and prefer learning alone; and (4) Understanding (sequential/global) which focuses on how information is understood. Sequential students understand information in linear, logical steps, prefer convergent thinking and analysis, and tend to lack the big picture; whereas global students understand information in large leaps, prefer system thinking and synthesis, and tend to grasp the big picture (Felder \& Silverman, 1988).

A parallel teaching style model was also proposed by Felder and Silverman (1988) which "classified instructional methods according to how well they address the proposed learning style components." (p. 674). According to this model, a teacher's teaching style is defined by the answers to four questions: (1) what type of information is emphasized by the instructor: concrete or abstract?; (2) what mode of presentation is stressed: visual or verbal?; (3) what mode of student participation is facilitated by the presentation: active or passive?; and (4) what type of perspective is provided on the information presented: sequential —step-by-step progression, or global - context and relevance? (Felder \& Silverman, 1988).

Therefore, four dimensions were suggested as corresponding teaching styles: (1) Content (concrete/abstract) which focuses on the type of information that is presented. The concrete information includes facts, data, and experiments; whereas the abstract information tackles principles, theories, and models; (2) Presentation (visual/verbal) which focuses on the mode of information that is stressed. The visual mode includes pictures, diagrams, films, and demonstrations; while the verbal mode contains lectures, readings, and discussions; (3) Student Participation (active/passive) which focuses on the mode of student participation. Active participation is facilitated by students' talk, movement, and reflection as compared to passive participation in which students only watch and listen; and (4) Perspective (sequential/global) which focuses on the type of perspective that is provided on the information presented. Sequential perspective follows a step-by-step progression; whereas global perspective focuses on context and relevance (Felder \& Silverman, 1988).

Felder and Silverman (1988) concluded (Table 1) that the concrete-abstract teaching styles correspond to the sensing-intuitive learning styles, the visual-verbal teaching styles correspond to the visual-verbal learning styles, 
the active-passive teaching styles correspond to the active-reflective learning styles, and the sequential-global teaching styles correspond to the sequential-global learning styles.

Table 1. Dimensions of learning and teaching styles

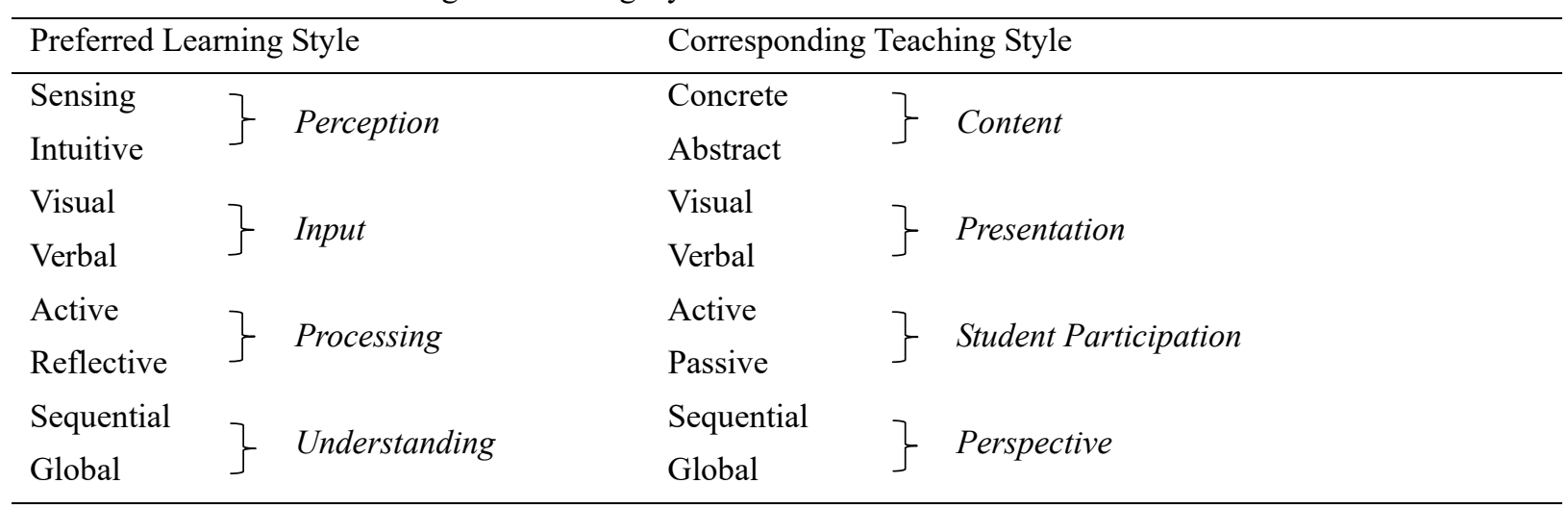

\subsection{Matching Preferred Teaching Styles (PTS) to Preferred Learning Styles (PLS)}

Both learning and teaching styles are significant components of the teaching and learning process. Several researchers suggested a balanced teaching style in order to bridge the gap between learners' PLS and teachers' PTS as well as to accommodate different learning styles (Melton, 1990; Felder \& Henriques, 1995; Oxford \& Ehrman, 1995; Ried, 1995; Brown, 2000; Peacock, 2001). Matching teaching styles to learning styles enables students an equal chance to learning, allows them to realize their strengths and weaknesses, and positively affects their learning, attitude, behavior, and motivation (Oxford et al., 1991; Felder \& Henriques, 1995; Reid, 1995; Peacock, 2001). Reid (1995) indicated that "matching teaching style and learning style gives all students an equal chance in the classroom and builds student self-awareness" (p. 43). Brown (2000) confirmed that students' motivation, performance, and achievement will increase when their learning styles are matched with teaching styles. Felder and Silverman (1988) concluded that "most of the learning and teaching style components parallel one another. A student who favors intuitive over sensory perception, for example, would respond well to an instructor who emphasizes concepts (abstract content) rather than facts (concrete content); a student who favors visual perception would be most comfortable with an instructor who uses charts, pictures, and films." (p. 674).

Since matching teaching styles to learning styles proved to have a positive impact on learning outcomes, a mismatch between PLS and PTS may lead to learning failure and frustration (Reid, 1995). Felder and Silverman (1988) claimed that a mismatch between learning and teaching styles could make students "become bored and inattentive in class, do poorly on tests, get discouraged about the courses, the curriculum, and themselves, and in some cases change to other curricula or drop out of school" (p. 674). Some researchers emphasized that style conflicts may lead to "style wars" which can have serious consequences in EFL learning (Oxford el al., 1991). One way to avoid style conflicts is a balanced teaching style in which teachers adapt their teaching styels to meet the needs of their students. Peacock (2001) proposed that "teachers should strive for a balanced teaching style that does not excessively favor any one learning style - rather that tries to accommodate multiple learning styles" (p. 15). Teachers should accommodate all learning styles through their instructional methods, classroom activities, and lesson plans (Oxford el al., 1991; Felder \& Henriques, 1995; Peacock, 2001). Felder and Silverman (1988) concluded that an ideal classroom setting for teaching EFL would be one that has a balanced teaching style in which teachers adapt their instruction to address all learning styles.

\section{Method}

\subsection{Research Design}

This study was designed to investigate the difference between EFL students' preferred learning styles and EFL teachers' preferred teaching styles. The study identified the preferred learning styles among Saudi EFL students and the preferred teaching styles among EFL teachers, as well as examined whether there was a statistically significant difference between students' PLS and teachers' PTS. The collected data was coded and analyzed using the Statistical Package for Social Sciences (SPSS) software. Descriptive statistics (frequency distributions, percentages, means, and standard deviations) were computed to identify PLS and PTS. Independent samples 
t-test was used to examine whether there was a statistically significant difference between students' preferred learning styles and teachers' preferred teaching styles.

\subsection{Data Collection}

Data was collected from a sample of Saudi EFL students $(n=130)$ and a sample of EFL teachers $(n=102)$ in several Saudi public and private universities. A self-reporting questionnaire has been considered by many researchers as the most accurate method of identifying and measuring learning and teaching styles. Therefore, this study employed a survey questionnaire as a method of data collection. Two instruments were used to examine the participants' learning and teaching styles:

The Index of Learning Style (ILS), developed by Felder and Soloman (1996), is a self-report, 44-item questionnaire designed to assess students' preferences on four dimensions of the Felder-Silverman model (Sensing/Intuitive, Visual/Verbal, Active/Reflective, and Sequential/Global).

The Index of Teaching Style (ITS), developed by the author as an adaptation of the ILS, is a self-report, 44-item questionnaire designed to assess teachers' preferences on four dimensions of the Felder-Silverman model (Concrete/Abstract, Visual/Verbal, Active/Passive, and Sequential/Global). Some items were reworded in order to fit the teacher's tasks.

\subsection{Validity and Reliability}

The Index of Learning Style (ILS) instrument has been used in some studies to identify students' preferred learning styles. The Cronbach's alpha reliability coefficients of the ILS instrument indicated a high level of internal consistency as described in (Table 2).

Table 2. Cronbach's alpha reliability coefficients for ILS

\begin{tabular}{lll}
\hline Variable & Number of Items & Alpha \\
\hline Sensing/Intuitive & 11 & 0.62 \\
Visual/Verbal & 11 & 0.65 \\
Active/Reflective & 11 & 0.59 \\
Sequential/Global & 11 & 0.56 \\
ALL & 44 & 0.89 \\
\hline
\end{tabular}

The Index of Teaching Style (ITS) instrument has been developed by the author as an adaptation of the ILS to identify teachers' preferred teaching styles. The Cronbach's alpha reliability coefficients of the ITS instrument indicated a high level of internal consistency as described in (Table 3).

Table 3. Cronbach's alpha reliability coefficients for ITS

\begin{tabular}{lll}
\hline Variable & Number of Items & Alpha \\
\hline Concrete/Abstract & 11 & 0.69 \\
Visual/Verbal & 11 & 0.83 \\
Active/Passive & 11 & 0.58 \\
Sequential/Global & 11 & 0.59 \\
ALL & 44 & 0.84 \\
\hline
\end{tabular}

\section{Results}

\subsection{What Are the Most Preferred Learning Styles Among EFL Students?}

Examining students' preferred learning styles (Figure 1) revealed that the participants preferred the sensing $(66 \%)$, visual (78\%), active (72\%), and sequential (62\%) learning styles. 


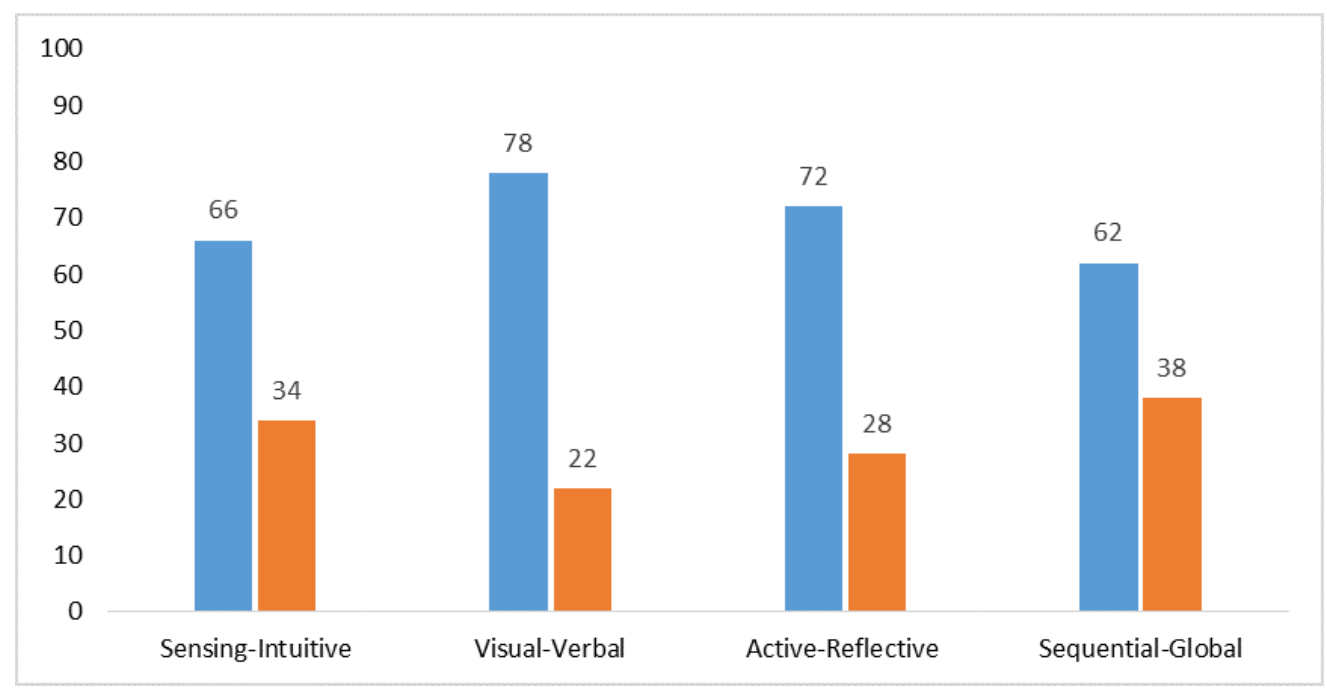

Figure 1. Descriptive statistics for students' Preferred Learning Styles (PLS)

4.2 What Are the Most Preferred Teaching Styles Among EFL Teachers?

Investigating teachers' preferred teaching styles (Figure 2) revealed that the participants preferred the abstract (67\%), verbal (65\%), passive (63\%), and global (68\%) teaching styles.

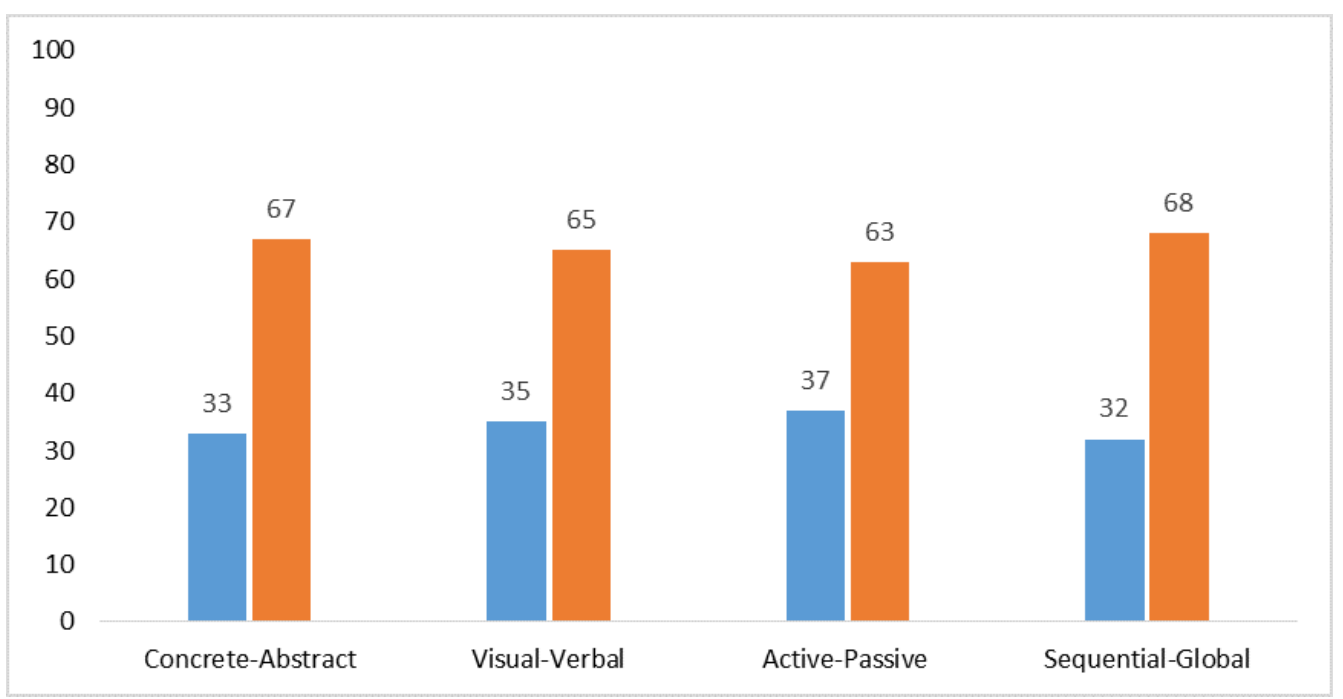

Figure 2. Descriptive statistics for teachers' Preferred Teaching Styles (PTS)

4.3 Is There a Statistically Significant Difference Between Students' Preferred Learning Styles and Teachers' Preferred Teaching Styles?

To investigate whether there was a statistically significant difference between students' preferred learning styles and teachers' preferred teaching styles, an independent-samples t-test was conducted. The significance level was set at $p<0.05$. The results (Table 4) showed that there was a statistically significant difference in the scores for students' sensing-intuitive learning styles $(\mathrm{M}=3.50, \mathrm{SD}=0.68)$ as compared to corresponding teachers' concrete-abstract teaching styles $(\mathrm{M}=3.35, \mathrm{SD}=0.30)$ conditions; $\mathrm{t}(230)=2.0743, \mathrm{p}=0.0392$. The results also indicated that there was a very statistically significant difference in the scores for students' visual-verbal learning styles $(\mathrm{M}=3.91, \mathrm{SD}=0.52)$ as compared to corresponding teachers' visual-verbal teaching styles $(\mathrm{M}=3.69$, $\mathrm{SD}=0.61$ ) conditions; $\mathrm{t}(230)=2.9632, \mathrm{p}=0.0034$. The results also revealed that there was a very statistically significant difference in the scores for students' active-reflective learning styles $(\mathrm{M}=3.79, \mathrm{SD}=0.62)$ as compared to corresponding teachers' active-passive teaching styles $(\mathrm{M}=3.57, \mathrm{SD}=0.64)$ conditions; $\mathrm{t}(230)=2.6448, \mathrm{p}=$ 
0.0087. The results also showed that there was a statistically significant difference in the scores for students' sequential-global learning styles $(\mathrm{M}=3.30, \mathrm{SD}=0.85)$ as compared to corresponding teachers' sequential-global teaching styles $(\mathrm{M}=3.10, \mathrm{SD}=0.56)$ conditions; $\mathrm{t}(230)=2.0520, \mathrm{p}=.0413$.

Table 4. Independent samples t-Test for student's Preferred Learning Styles (PLS) and Teachers' Preferred Teaching Styles (PTS)

\begin{tabular}{lcclccccc}
\hline $\begin{array}{l}\text { PLS } \\
\text { Students (n=130) }\end{array}$ & M & SD & $\begin{array}{l}\text { PTS } \\
\text { Teachers (n=102) }\end{array}$ & M & SD & t & df & P \\
\hline Sensing-Intuitive & 3.50 & 0.68 & Concrete-Abstract & 3.35 & 0.30 & 2.0743 & 230 & .0392 \\
Visual-Verbal & 3.91 & 0.52 & Visual-Verbal & 3.69 & 0.61 & 2.9632 & 230 & .0034 \\
Active-Reflective & 3.79 & 0.62 & Active-Passive & 3.57 & 0.64 & 2.6448 & 230 & .0087 \\
Sequential-Global & 3.30 & 0.85 & Sequential-Global & 3.10 & 0.56 & 2.0520 & 230 & .0413 \\
\hline
\end{tabular}

\section{Discussion}

The findings of this study revealed that the participanting students preferred the sensing, visual, active, and sequential learning styles. These results imply that Saudi EFL students are sensing learners. They understand new information best if they can see how it connects to the real world. They like concrete information such as facts and experimentations, rely on memorization and repetition, and tend to follow rules and procedures. They prefer class instruction that uses internal drills, flash cards, and practical material. The results also infer that Saudi EFL students are visual learners. They understand new information best when they see it in pictures, charts, diagrams, and demonstrations. They like class instruction that emphasizes visual material such as showing drawings and cartoons to introduce vocabulary words and using videotapes and films to teach pronunciation and speaking. The findings propose that Saudi EFL students are active learners. They understand new information best by doing something active with it such as discussing it, applying it, or explaining it to others. They also enjoy group work and find it difficult and boring to sit through lectures without doing anything physical. They prefer class instruction that has conversations, minidramas, and team competitions. It could also be concluded that Saudi EFL students are sequential learners. They understand new information best if information is introduced to them in small chunks and linear steps where each step follows logically from the previous one. They prefer class instruction that stresses grammatical structure and contrastive analysis. These findings are consistent with previous studies by Buxeda et al.; Constant; De Vita; Dee et al.; Kuri \& Truzzi; Livesay et al.; Lopes; Montgomery; Paterson; Rosati; Seery et al.; Smith et al.; Zywono (as cited in Felder \& Spurlin, 2005) which were conducted on students from several different majors including Engineering, Business, and Biology.

The results also showed that the participanting teachers preferred the abstract, verbal, passive, and global teaching styles. These findings imply that Saudi EFL teachers are abstract teachers. They like to present abstract information such as concepts, principles, and theories. They want their students to discover new relationships and dislike repetition and memorization. The results indicate that Saudi EFL teachers are verbal teachers. They enjoy presenting new information to their students in spoken and written words rather than in pictures and diagrams. They prefer to have their students listen to lectures and read material written on boards and in textbooks and handouts. The findings also conclude that Saudi EFL teachers are passive teachers. They prefer their students to watch and listen rather than move and talk. They tend to allow little or no time for discussion or problem-solving activities. It could also be concluded that Saudi EFL teachers are global teachers. They prefer their students to perceive and learn new information in large jumps and random order. They like to jump around from topic to topic, skip steps, and encourage their students to grasp the big picture.

The results showed that there was a statistically significant difference between students' sensing-intuitive learning styles and corresponding teachers' concrete-abstract teaching styles. These results suggest that students prefer concrete information such as facts and experimentations, rely on memorization and repetition, and enjoy class instruction that used drills, flash cards, and practical material; whereas their teachers like to present abstract information such as concepts, principles, and theories, dislike repetition and memorization, and disfavor teaching how things are connected and/or related.

The findings also indicated that there was a very statistically significant difference between students' visual-verbal learning styles and corresponding teachers' visual-verbal teaching styles. These results imply that 
students prefer to have new information presented in pictures, charts, diagrams, and demonstrations. They like visual material such as showing drawings and cartoons and using videotapes and films to learn English. On the other hand, teachers like presenting new information to their students in spoken and written words rather than in pictures and diagrams. They prefer to have their students listen to lectures and read textbooks and handouts.

The results also revealed that there was a very statistically significant difference between students' active-reflective learning styles and corresponding teachers' active-passive teaching styles. These results propose that students favor discussion and group work and learning that involved conversations, minidramas, and team competitions. However, teachers allow little or no time for discussion or problem-solving activities and prefer their students to watch and listen rather than move and talk.

The results also showed that there was a statistically significant difference between students' sequential-global learning styles and corresponding teachers' sequential-global teaching styles. These results imply that students prefer to be introduced to information in small linear steps and small details; whereas teachers like to provide their students with new information in large jumps and random order so that their students could grasp the big picture.

\section{Conclusion}

The learning styles of EFL Saudi students and the teaching styles of EFL teachers have a mismatch. Many EFL Saudi students are sensing, visual, active, and sequential; whereas most EFL teaching is abstract, verbal, passive, and global. While matching teaching styles to learning styles has been found to significantly enhance student's learning, achievement, attitudes, and behavior (Felder \& Henriques, 1995), a mismatch between learning and teaching styles has been reported to cause learning failure and frustration (Reid, 1995; Peacock, 2001). To overcome the mismatch, all teachers should adopt a balanced teaching style in which they could accommodate all learning styles (Reid, 1987; Oxford et al., 1992; Peacock, 2001). Teachers should be aware of their own teaching styles as well as their students' learning styles. Teachers should use teaching methods and instructional techniques that address all their students' needs. Lesson plans, presentations, and assessment tools should be designed to accommodate different learning styles. Teachers need to diversify their teaching styles in order to incorporate a variety of activities in class.

In EFL classroom settings, teachers should provide a balance of concrete information and conceptual information, e.g., providing students with word definitions, verb-subject agreement (sensing) as well as syntactical and semantic patterns (intuitive). Class material that emphasizes practical problem-solving methods (active) should be equally introduced with material that emphasizes fundamental understanding (reflective), e.g., working in small groups and encouraging dialogues and role-playing (active) as well as allowing students to think about what they have been told and assign brief writing exercises (reflective). Presenting new information should not be limited to the traditional lecture format (verbal) but it should be also presented in the form of pictures, graphs, videotapes, and demonstrations (visual) (Felder and Henriques, 1995). Teachers need to give their students more control over their learning, give them more opportunities to learn, and involve them in planning their lessons and tasks. EFL materials and activities should be designed to account for different learning styles. EFL teachers' training programs should also focus on the advantages and disadvantages of the match and mismatch between learning and teaching styles (Peacock, 2001).

The present study was limited to the feedback received from participants (students and teachers) in their responses to two survey instruments that were employed: the Index of Learning Style (ILS) and the Index of Teaching Style (ITS). A future study with interviews and observations might provide more accurate and reliable findings. A qualitative study might also provide a deeper understanding of the differences between learning and teaching styles. A further study on the relationship between learning styles and students' achievement is also recommended.

\section{References}

Brown, H. D. (2000). Principles of Language Teaching and Learning. White Plains, NY: Longman.

Felder, R., \& Henriques, E. (1995). Learning and Teaching Styles In Foreign and Second Language Education. Foreign Language Annals, 28(1), 21-31. https://doi.org/10.1111/j.1944-9720.1995.tb00767.x

Felder, R. M., \& Silverman, L. K. (1988). Learning and teaching styles in engineering education. Engineering Education, 78(7), 674-681.

Felder, R. M., \& Soloman, B. A. (n.d.). Index of learning styles questionnaire. Retrieved from https://www.webtools.ncsu.edu/learningstyles 
Felder R. M., Spurlin, J. (2005). Applications, reliability and validity of the Index of Learning Styles. International Journal of Engineering Education, 21, 103-12.

Grasha, A. F. (1996). Teaching with style. Pittsburgh, PA: Alliance.

Melton, C. D. (1990). Bridging the Cultural Gap: A study of Chinese students' learning style preferences. RELC Journal, 21(1), 29-54. https://doi.org/10.1177/003368829002100103

Oxford, R. L. (2001). Language learning styles and strategies . In M. Celce-Murcia (Ed., pp. 359-366).

Oxford, R. L., \& Ehrman, M. (1995). Adults, language learning strategies in an intensive foreign language program in the United States. System, 23, 359-386. https://doi.org/10.1016/0346-251x(95)00023-d

Oxford, R. L., Ehrman, M., and Lavine, R. Z. (1991). Style wars: teacher-student style conflicts in the language classroom. In Magnan, S.S. (Ed.), Challenges in the 1990s for College Foreign Language Programs: Boston, MA: Heinle \& Heinle. https://doi.org/10.2307/329570

Peacock, M. (2001). Match or mismatch? Learning styles and teaching styles in EFL. International Journal of Applied Linguistics, 11, 1-20. https://doi.org/10.1111/1473-4192.00001

Reid, J. M. (1987). The Learning Style Preferences of ESL Students. TESOL Quarterly, 21(1), 87-110. https://doi.org/10.2307/3586356

Reid, J. M. (1995). Preface. In J. Reid (Ed.). Learning styles in the ESL/EFL classroom. (pp. viii-xvii). New York: Heinle and Heinle Publishers. https://doi.org/10.1017/CBO9781139172721.001

\section{Copyrights}

Copyright for this article is retained by the author(s), with first publication rights granted to the journal.

This is an open-access article distributed under the terms and conditions of the Creative Commons Attribution license (http://creativecommons.org/licenses/by/4.0/). 